\title{
EFEKTIVITAS PARTISIPASI MASYARAKAT DALAM PENINGKATAN PELAYANAN PUBLIK DI KELURAHAN TOBEKGODANG KECAMATAN TAMPAN
}

\author{
Pebriana Marlinda, Eka dan Adia Ferizko \\ Fakultas Ilmu Administrasi Universitas Lancang Kuning \\ Email : pebrianamarlinda@unilak.ac.id
}

\begin{abstract}
This study aims to see who is involved in public services in the Tobekgodang District of Tampan District, which has been regulated in the Regulation of the Minister of State for Administrative Reform No. 13 of 2009 concerning Guidelines for Improving the Quality of Public Services. The design of this study uses descriptive qualitative methods that will reinforce and review the data in general in the form of documents relating to public facilities within the scope of public services Tobekgodang District Tampan District. In addition, so that the research objectives can be used also use primary data in the form of interviews with research informants, namely: Head of Tobekgodang Village, Secretary of Tobekgodang Village, Tobek godang Village Staff and Tobekgodang Village Community. The results of this study indicate that the participation of the community in Tobekgodang Subdistrict, Tampan District has been effective in improving public services in Tobekgodang Subdistrict, Tampan District.
\end{abstract}

Keywords: Effectiveness, Participation and Public Services

\begin{abstract}
Abstrak
Penelitian ini bertujuan melihat sejauh mana efektivitas partisipasi masyarakat dalam peningkatan pelayanan publik di Kelurahan Tobekgodang Kecamatan Tampan, sebagaimana yang telah diamatkan dalam Peraturan Menteri Negara Pendayagunaan Aparatur Negara Nomor: 13 Tahun 2009 Tentang Pedoman Peningkatan Kualitas Pelayanan Publik.Desain penelitian ini menggunakan metode kualitatif deskriptif yang akan memahami dan mengkaji data-data sekunder secara mendalam berupa dokumen-dokumen yang berkaitan dengan efektivitas partisipasi masyarakat dalam peningkatan pelayan publikdi Kelurahan Tobekgodang Kecamatan Tampan. Selain itu, agar tujuan penelitian dapat tercapai peneliti juga menggunakan data primer berupa hasil wawancara dengan informan penelitian yaitu: Lurah Kelurahan Tobekgodang, Sekretaris Kelurahan Tobekgodang, Pegawai Kelurahan Tobekgodang dan Masyarakat Kelurahan Tobekgodang. Kesimpulan dari hasil penelitian ini menunjukkan bahwa partisipasi masyarakat di Kelurahan Tobekgodang Kecamatan Tampan sudah efektif dalam rangka peningkatan pelayan publik di Kelurahan Tobekgodang Kecamatan Tampan.
\end{abstract}

Kata Kunci : Efektivitas, Partisipasi dan Pelayanan Publik

\section{PENDAHULUAN}

Memberikan pelayanan public yang baik kepada masyarakat disegala aspek merupakan tanggungjawab pemerintah.Pelayanan public disini berupa pelayanan dalam bentuk barang maupun jasa. Membahas tentang pemberian pelayanan dalam bentuk barang dan jasa yang dimaksud tidak hanya sebatas bagaimana kebutuhan masyarakat akan pelayanan secara jumlah (kuantitas), tetapi juga bagaimana pelayanan yang diberikan itu dapat terpenuhi secara kualitas.Dalam pelaksanaannya, pelayanan public yang saat ini sering terjadi banyak ditemui permasalahaan-permasalahan sehingga perlu adanya perbaikan-perbaikan dalam rangka peningkatan pelayanan public. 
Di Indonesia, upaya memperbaiki pelayanan sebenarnya juga telah sejak lama dilaksanakan oleh pemerintah, antara lain melalui Inpres No. 5 Tahun 1984 tentang Pedoman Penyederhanaan dan Pengendalian Perijinan di Bidang Usaha. Upaya ini dilanjutkan dengan Surat Keputusan Menteri Negara Pendayagunaan Aparatur Negara No. 81/1993 tentang Pedoman Tatalaksana Pelayanan Umum. Untuk lebih mendorong komitmen aparatur pemerintah terhadap peningkatan mutu pelayanan, maka telah diterbitkan pula Inpres No. 1 Tahun 1995 tentang Perbaikan dan Peningkatan Mutu Pelayanan Aparatur Pemerintah Kepada Masyarakat. Pada perkembangan terakhir telah diterbitkan pula Keputusan Menpan No. 63/KEP/M.PAN/7/2003 tentang Pedoman Umum Penyelenggaraan Pelayanan Publik.Selain itu, pemerintah juga mengeluarkan Undang-Undang Nomor 25 Tahun 2009 Tentang Pelayanan Publik. Berdasarkan kebijakan-kebijakan yang telah di keluarkan oleh pemerintah pusat tersebut, maka daerah memiliki kewajiban untuk mengimplementasikan kebijakan-kebijakan tersebut disetiap level pemerintahan yang telah ditetapkan dalam kebijakan tersebut.

Kota pekanbaru yang merupakan Ibu Kota dari Provinsi Riau memiliki 12 (dua belas) kecamatan, untuk lebih jelasnya dapat dilihat pada tabel berikut ini.

Kota Pekanbaru memiliki 12 kecamaatn dan 60 kelurahan.Dalam penelitian ini penelti memilih lokasi penelitian di Kelurahan Tobekgodang yang merupakan salah satu kelurahan hasil pemekaran wilayah di Kecamatan Tampan pada tahun 2017 ini.Terhitung belum genap satu tahun Kelurahan Tobekgodang ini berdiri.

Dengan umur pendirian kelurahan ini yang masih sangat singkat belum genap satu tahun, namun Kelurahan Tobekgodang telah menunjukkan potensi untuk berkembang yang sangat baik meskipun banyak terdapat permasalahan-permasalahan.Dalam memberikan pelayanan kepada masyarakat pihak Kelurahan Tobekgodang telah berusaha memberikan pelayanan yang baik.Seperti contoh dalam pengurusan surat-menyurat dapat diselesaikan dalam waktu yang sangat cepat (10-20 menit) selesai.Namun dalam pelaksanaannya pihak Kelurahan Tobekgodang menemui permasalaha-permasahan terkait fasilitas yang tersedia. Dimana kantor kelurahan yang menjadi tempat aktivitas Kelurahan Tobekgodang masih berstatus sewa, jadi Kelurahan Tobekgodang belum memiliki gedung tersendiri. Disamping itu, ketersediaan fasilitas dalam menunjang kegiatan pelayanan kepada masyarakat masih belum memadai.Seperti ketersedian printer yang hanya tersedia satu unit saja. Berdasarkan fenomenafenomena tersebut maka peneliti tertarik untuk melakukan penelitian dengan judul " Efektivitas Partisipasi Masyarakat Dalam Peningkatan Pelayanan Publik Di Kelurahan Tobekgodang Kecamatan Tampan".

\section{METODE}

\subsection{Lokasi Penelitian}

Penelitian ini dilaksanakan di Kelurahan Tobekgodang Kecamatan Tampan Kota Pekanbaru.

\subsection{Teknik Pengumpulan Data}

Pengumpulan data pada penelitian ini menggunakan beberapa teknik supaya memperoleh data yang lengkap. Adapun teknik-teknik yang digunakan dalam pengumpulan data adalah sebagai berikut:

\section{Teknik Wawancara}

Teknik wawancara digunakan untuk memperoleh data/informasi tentang efektivitas partisipasi masyarakat dalam peningkat pelayanan publik di Kelurahan Tobekgodang Kecamatan Tampan dengan menjadika Lurah Tobekgodang, Sekretaris Kelurahan Tobekgodang, pegaiwai Kelurahan Tobekgodang dan masyarakat. 


\section{Observasi}

Pada metode ini penelitian dilakukan dengan pengamatan atau melihat langsung terhadap efektivitas partisipasi masyarakat dalam peningkat pelayanan publik di Kelurahan Tobekgodang Kecamatan Tampan serta untuk mendukung atau membandingkan dengan data yang diperoleh dari wawancara.

\section{Teknik Dokumentasi}

Teknik dokumentasi dalam penelitian ini digunakan untuk memperoleh data penunjang penelitian berupa struktur organisasi, profil lembaga dan dokumen-dokumen terkait efektivitas partisipasi masyarakat dalam peningkat pelayanan publik di Kelurahan Tobekgodang Kota Pekanbaru.

\section{Teknik Penentuan Informan dan Informan penelitian}

Dalam penelitian ini peneliti menggunakan teknik purposive sampling untuk menentukan Informan penlitian.Hal ini dilakukan dengan berbagai pertimbangan agar tujuan dari penelitian dapat tercapai.Selanjutnya peneliti berusaha secara cermat menentukan informan yang tepat.Peneliti berusaha mengetahui informan secara mendalam sehingga informan yang terpilih dapat menjawab pertanyaanpertanyaan yang diajukan dengan tepat sehingga diharapkan tujuan penelitian dapat tercapai.

\subsection{Teknik Validasi Data}

Untuk menguji validitas data dalam penelitian ini peneliti menggunakan teknik triangulasi, karena sumber data serta teknik pengumpulan data banyak dan beragam maka dapat diuji validitas sebagaimana data dikatan valid apabila terdapat informasi yang sama dari sumber yang berbeda atau dengan menggunakan teknik pengumpulan yang berbeda. Hal ini dilakukan untuk menghindari terjadinya bias yang terjadi pada informan kunci (key informant bias) dalam penelitian. Dengan melakukan triangulasi peneliti memeriksa validitas data dengan membandingkan hasil dari teknik pengumpulan yang berbeda (teknik triangulasi) atau membandingkan hasil dari sumber yang berbeda (triangulasi sumber).

\subsection{Analisis Data}

Teknik analisis data yang digunakana dalam penelitian ini adalah analisis interaktif.Data yang diperoleh berupa kata-kata atau kalimat yang dipisah menurut kategorinya kemudian dianalisis untuk mendapatkan gambaran mengenai fakta yang ada atau untuk memperoleh kesimpulan.

Langkah-langkah teknik analisis data yang digunakan adalah:

\section{Reduksi Data}

Reduksi data adalah memilah-milah data, difokuskan pada hal-hal yang penting.Laporan lapangan sebagai bahan mentah disederhanakan, direduksi, disusun lebih sistematis, ditonjolkan pokok-pokok yang penting sehingga lebih mudah dikendalikan.Reduksi ini dapat pula membantu memberikan kode pada aspek-aspek tertentu. Reduksi data sebagai proses pemulihan pemusatan perhatian atau penyederhanaan, pengabstrakan dan transformasi data kasar yang muncul dari catatan lapangan. Reduksi data berlangsung terus menerus selama proses penelitian berlangsung dan berlanjut terus sesudah penelitian lapangan sampai laporan akhir lengkap.

\section{Penyajian Data}

Penyajian data merupakan upaya penyususnan sekumpulan informasi ke dalam suatu matriks/konfigurasi yang mudah dipahami. Penyajian data yang mudah dipahami adalah cara utama menganalisis data kualitatif yang valid.

\section{Menarik Kesimpulan}

Data-data yang diperoleh pada waktu observasi dan penelitian dikumpulkan. Kemudian data tersebut dihubungkan dan dibandingkan antara satu dengan yang lain sehingga mudah ditarik kesimpulan sebagai jawaban atas setiap permasalahan yang ada. Setelah kesimpulan diambil maka dapat diperoleh gambaran 
yang jelas mengenai efektivitas partisipasi masyarakat dalam peningkatan pelayanan publik di Kelurahan Tobekgodang Kecamatan Tampan.

\section{HASIL DAN PEMBAHASAN}

Untuk meningkatkan kualitas pelayanan publik, salah satu persyaratan harus menempatkan masyarakat sebagai sentral sekaligus sebagai owner dalam pelayanan.Untuk itu partisipasi masyarakat dalam pelayanan publik perlu ditingkatkan. Peraturan Menteri Pendayagunaan Aparatur Negara Nomor 13 Tahun 2009 tentang Pedoman Peningkatan Kualitas Pelayanan Publik Dengan Partisipasi Masyarakat (disingkat KATALIKPARKAT) sebagai salah satu metode peningkatan partisipasi masyarakat dengan keluhan (pengaduan) sebagai dasar perbaikan.

Kementerian Pendayagunaan Aparatur Negara dan Reformasi Birokrasi telah menetapkan 6 (enam) strategi dalam meningkatkan pelayanan publik, meliputi :

1. Deregulasi dan Debirokratisasi di bidang pelayanan publik,

2. peningkatan profesionalisme pejabat di bidang pelayanan publik,

3. korporatisasi unit pelayanan publik,

4. pengembangan dan pemanfaatan e-government bagi instansi pelayanan publik,

5. peningkatan partisipasi masyarakat di bidang pelayanan publik dan

6. pemberian penghargaan dan sanksi kepada unit pelayanan masyarakat.

Dengan bertitik tolak dari pendapat Denhardt dan Denhardt dalam Bahan Ajar TOT Diklat Pelayanan Publik (2011), bahwa publik sebagai citizen merupakan akar dari manajemen publik perspektif baru. Maka dalam penulisan artikel ini penulis akan fokus pada pembahasan peningkatan partisipasi masyarakat di bidang pelayanan publik. Dari strategi diatas nampak bahwa pemerintah mulai mengambil kebijakan untuk menempatkan publik (masyarakat) sebagai sentral dalam peningkatan kualitas pelayanan publik, dengan bercermin pada pengalaman masa lalu karena terlalu "government centered" seringkali mengakibatkan munculnya ketidakpuasan masyarakat sebagai pelanggan, seperti lambat, berbelit-belit dan mahal. Perubahan paradigma dari pelayanan yang bersifat sentralistik ke arah pengelolaan yang berorientasi kepuasan pelanggan tersebut memiliki beberapa karakteristik (Bahan Ajar TOT Pelayanan Publik, 2011), antara lain :

1. lebih memfokuskan pada pengaturan melalu8 berbagai kebijakan yang memfasilitasi bagi berkembangnya kondisi yang kondusif bagi kegiatan pelayanan kepada masyarakat,

2. lebih memfokuskan kepada pemberdayaan masyarakat, sehingga akan terbangun rasa ikut memiliki,

3. menerapkan sistem kompetisi untuk jenis pelayanan publik tertentu sehingga masyarakat akan memperoleh pelayanan yang berkualitas,

4. fokus pada pencapaian visi, misi, tujuan maupun sasaran yang berorientasi pada pencapaian hasil (outcome), dan

5. mengutamakan pemenuhan apa yang diinginkan masyarakat.

Berdasarkan hal-hal yang telah dijelakan sebelumnya maka dari itu peneliti akan membahas peningkatan pelayanan publik dari sudut pandang partisipasi masyarakat yang ada di Kelurahan Tobekgodang. Untuk itu peneliti akan melihat partisipasi masyarakat tersebut melalui : Produktivitas, Kemampuan adaptasi kerja, Kepuasan kerja, Kemampuan berlaba , Pencarian sumber daya. Untuk lebih jelasnya mengenai partisipasi masyarakat Kelurahan Tobekgodang dalam peningkatan pelayanan publik akan dibahas oleh peneliti sebagai berikut. 


\section{Produktivitas}

Pelayanan publik merupakan kegiatan atau serangkaian kegiatan dalam rangka memenuhi kebutuhan masyarakat yang dilakukan oleh penyelenggara pelayanan publik. Menurut UndangUndang Nomor 25 Tahun 2009 tentang Pelayanan Publik (UU No. 25 Th. 2009) penyelenggara pelayanan publik adalah setiap institusi penyelenggara negara, korposasi, lembaga independen yang dibentuk berdasarkan undang-undang untuk kegiatan pelayanan publik, dan badan hukum lain yang dibentuk semata-mata untuk kegiatan pelayanan publik. Penyelenggara pelayanan publik setidaknya terdiri atas: (1) organisasi penyelenggara pelayanan publik yang terdiri atas satuan kerja penyelenggara pelayanan publik yang berada dilingkungan institusi penyelenggara negara, korporasi, lembaga independen yang dibentuk berdasarkan undangundang untuk kegiatan pelayanan publik, dan badan hukum lain yang dibentuk semata-mata untuk kegiatan pelayanan publik; dan (2) pelaksana pelayanan publik terdiri atas pejabat, pegawai, petugas, dan setiap orang bekerja didalam organisasi penyelenggara yang bertugas melaksanakan tindakan atau serangkaian kegiatan pelayanan publik. Sedangkan masyarakat yang terdiri atas seluruh pihak, baik warga negara maupun penduduk sebagai orang perseorangan, kelompok, maupun badan hukum yang berkedudukan sebagai penerima manfaat pelayanan publik, baik secara langsung maupun tidak langsung.

Keterlibatan masyarakat dalam peningkatan pelayanan publik di Kelurahan Tobekgodang ini sangatlah besar. Terlihat semenjak didirikannya Kelurahan Tobekgodang yang terhitung belum genap 2 tahun tetapi sudah sangat banyak mendulang prestasi. Berikut beberapa kutipan wawancara penulis di Kelurahan Tobek godang.

"kelurahan kami ini baru saja dibentuk terhitung belum genap 2 tahun. Karena masih baru didirikan sehingga masih banyak kekurangan. Yang nampak jelas yaitu kekurangan dari ketersediaan fasilitas dan sumber daya manusia. Gedung tempat aktifitas kegiatan kelurahan ini saja masih menyewa. Jatuhnya kelurahan Tobekgodang belum memiliki gedung sendiri. Waktu pertama didirikan pemerintah hanya menyediakan kursi beserta meja saja. Selebihnya sebagaimana yang nampak hari ini adalah hasil sumbangan dari masyarakat" (wawancara dengan Lurah Tobekgodang)

"sejauh ini kendala yang dihadapi memang tidak terlalu berat yang dapat mengakibatkan pelayanan dikelurahan ini terhambat. Dalam memberikan pelayanan kami mencoba untuk total, sebisa mungkin apa yang dibutuhkan masyarakan secepat mungkin kami selesaikan. Hanya saya ketersediaan sumber daya manusia dan perangkat pendudukung pelayanan blum memadai. Kami disi terbatas dengna printer,printer yang tersedia hanya satu. Dan keperluan yang berkaitan dengan sistem online juga belum bisa kami laksanakan. Hal ini dikarenakan keterbatasan dana dan sumberdaya manusia yang ahli. (wawancara dengan seklur Tobekgodang)

Dari kutipan wawancara diatas dapat diketahui sejauh ini pihak kelurahan tobekgodang mampu memberikan pelayanan yang baik kepada masyarakatnya meskipun dengan segala keterbatasa dan kekurangan. Sebagian keterbatasan dan kekurangan itu dapat dibantu oleh masyarakat yang sangat antusias untuk membatu pihak kelurahan.

\section{Kemampuan adaptasi kerja}

Bagaimana pelayanan publik dilaksanakan oleh penyelenggara pelayanan publik dapat dilihat dari Indikator pelayanan publik yang dapat dipergunakan adalah indikator yang dikembangkan oleh Zeithaml dkk. (1990), yaitu: (1) wujud; (2) keandalan; (3) daya tanggap; (4) jaminan; dan (5) empati. Wujud merupakan bentuk fisik yang ditunjukan dengan adanya sarana dan prasarana pendukung 
pelayanan publik serta penampilan dari pelaksana pelayanan publik itu sendiri.Keandalan merupakan kemampuan organisasi pelayanan publik untuk memberikan publik sesuai dengan yang dijanjikan dan akurat.Daya tanggap merupakan keinginan pelaksana pelayanan publik untuk membantu masyarakat dan memberikan pelayanan secara cepat.Jaminan merupakan kemampuan dan pengetahuan pelaksana pelayanan publik yang mampu menumbuhkan rasa percaya masyarakat.Empati merupakan pemberian perhatian pribadi dalam upaya memahami kebutuhan masyarakat.Masingmasing indikator tersebut dapat diukur dari sikap ketidakpuasan masyarakat.Ketidakpuasan ini merupakan perasaan atau penilaian kurang baik masyarakat terhadap kualitas pelayanan publik yang diberikan oleh penyelenggara pelayanan publik (Bitner dan Hubbert, 1994 dalam Johnson, 1995).Ketidakpuasan ini ditunjukan dengan pengaduan masyarakat terhadap pelayanan publik.

Berikut ini kutipan wawancara penulis dengan Lurah Tobekgodak yaitu sebagai berikut:

"selama ini disetiap kegiatan kami dari pihak kelurahan selalu melibatkan masyarakat dalam berbagai kegiatan yang kami laksanakan. Mulaidari kegiatan musyawarah, gotong royong, kegiatan-kegiatan formal Kelurahan. Dan saya sebagai lurah juga bersyukur masyarakat saya mau untuk membatu dan terlibat disetiap kegiatan yang pihak kelurahan laksanakan. Keterlibatan ini baik dalam bentuk material maupun moril. Salah satu contohnya dalam setiap kegiatan masyarakat sering menyumbang dalam bentuk konsumsi maupun menyumbangkan tenaganya dalam membantu. (wawancara dengan Lurah Tobekgodang)

Dari hasil wawancara diatas dapat diketahui bahwa pihak kelurahan telah menjadikan masyarakat sebagai sentral dalam peningkatan pelayanan publik. Dimana masyarakat ikut terjun langsung dalam proses pelyanan publik di Kelurahan Tobekgodang. Ini terbukti dari dilibatkannya masyarakat dalam berbagai proses pengambilan keputusan dan keterlibatan langsung dalam pelayanan publik.

\section{Kepuasan kerja}

Pelayanan publik merupakan kegiatan atau serangkaian kegiatan dalam rangka memenuhi kebutuhan masyarakat yang dilakukan oleh penyelenggara pelayanan publik. Menurut UndangUndang Nomor 25 Tahun 2009 tentang Pelayanan Publik (UU No. 25 Th. 2009) penyelenggara pelayanan publik adalah setiap institusi penyelenggara negara, korposasi, lembaga independen yang dibentuk berdasarkan undang-undang untuk kegiatan pelayanan publik, dan badan hukum lain yang dibentuk semata-mata untuk kegiatan pelayanan publik. Penyelenggara pelayanan publik setidaknya terdiri atas: (1) organisasi penyelenggara pelayanan publik yang terdiri atas satuan kerja penyelenggara pelayanan publik yang berada dilingkungan institusi penyelenggara negara, korporasi, lembaga independen yang dibentuk berdasarkan undangundang untuk kegiatan pelayanan publik, dan badan hukum lain yang dibentuk semata-mata untuk kegiatan pelayanan publik; dan (2) pelaksana pelayanan publik terdiri atas pejabat, pegawai, petugas, dan setiap orang bekerja didalam organisasi penyelenggara yang bertugas melaksanakan tindakan atau serangkaian kegiatan pelayanan publik. Sedangkan masyarakat yang terdiri atas seluruh pihak, baik warga negara maupun penduduk sebagai orang perseorangan, kelompok, maupun badan hukum yang berkedudukan sebagai penerima manfaat pelayanan publik, baik secara langsung maupun tidak langsung.Pelayanan publik merupakan kegiatan atau serangkaian kegiatan dalam rangka memenuhi kebutuhan masyarakat yang dilakukan oleh penyelenggara pelayanan publik.

"sejauh ini disetiap kegiatan masyarakat Kelurahan Tobekgodang menurut saya sangat membantu. Sebagaimana yang saya sampaikan tadi bahwa bantuan tersebut berbentuk materil dan moril. Kenapa saya katakan sangat membantu, karena dengan bantuan yang diberikan seperti printer, perbaikan lokasi luar kantor, gorden, lokasi rapat yang terdapat diluar kantor juga merupakan hasil sumbangan dari masyarakat. Semua itu berdampak pada kegiatan-kegiatan 
di Kelurahan dalam upaya peningkatan pelayanan publik. Kenapa demikian, karena dengan adanya bantuan-bantuan tersebut membatu kelancaran kegiatan pelayanan di Keruhan Tobekgodang Kecamatan Tampan”. (wawancara dengan Seklur Kelurahan Tobekgodang)

Dari hasil wawancara diatas dapat diketahui keterlibatan masyarakat sangat membantu pihak kelurahan Tobekgodang dalam melaksanakan tugas kelurahan. Pihakkelurahanpun sangat meapresia keinginan masyarakat atau kesedian masyarakat untuk membantu pihak kelurahan.

\section{Kemampuan berlaba}

Sebagaimana diketahui di era digital saat ini, masyarakat tidak lagi dijakan sebagai pihak yang hanya menerima pelayanan secara bersih saja. Pihak yang memberi layanan saat sekarang harus mampu memberdayakan keberadaan masyarakat. Sehingga masyarakat tidak hanya menerima pelayanan begitu saja tetapi juga terlibat dalam proses kegiatannya. Dalam hal ini yaitu keikut sertaan masyarakat dalam mewujudkan peningkatan pelayanan publik di Kelurahan Tobekgodang. Berikut kutipan wawancara penulis dengan Lurah Tobekgodang.

"di RT saya kami menyediakan air bersih untuk masyarakat dalam, dimana setiap kepala keluarga akan dipungut biaya setiap bulannya. Disamping itu kami juga memiliki usaha penyewaan kursi dan tenda untuk acara-acara. Hasil yang didapatkan akan menjadi milik bersama, maksudnya milik masyarakat yang juga akan dipergunakan untuk pemeliharaan dan kebutuhan kegiatan masyarakat lainnya".

Dari hasil wawancara penulis dengan salah satu RT yang terdapat di Kelurahan Tobekgodak diatas dapat diketahui bahwa masyarakat di Kelurahan Tobek godang telah mampu untuk mendatangkan income bagi wilayahnya sendiri. Sebagaimana disebutkan bahwa di Kelurahan Tobekgodang usahaair bersih milik masyarakat yang dipergunakan untuk masyarakat juga.

\section{Pencarian sumber daya}

Menurut Undang-Undang Nomor 25 Tahun 2009 tentang Pelayanan Publik (UU No. 25 Th. 2009) penyelenggara pelayanan publik adalah setiap institusi penyelenggara negara, korposasi, lembaga independen yang dibentuk berdasarkan undang-undang untuk kegiatan pelayanan publik, dan badan hukum lain yang dibentuk semata-mata untuk kegiatan pelayanan publik. Penyelenggara pelayanan publik setidaknya terdiri atas: (1) organisasi penyelenggara pelayanan publik yang terdiri atas satuan kerja penyelenggara pelayanan publik yang berada dilingkungan institusi penyelenggara negara, korporasi, lembaga independen yang dibentuk berdasarkan undangundang untuk kegiatan pelayanan publik, dan badan hukum lain yang dibentuk semata-mata untuk kegiatan pelayanan publik; dan (2) pelaksana pelayanan publik terdiri atas pejabat, pegawai, petugas, dan setiap orang bekerja didalam organisasi penyelenggara yang bertugas melaksanakan tindakan atau serangkaian kegiatan pelayanan publik. Sedangkan masyarakat yang terdiri atas seluruh pihak, baik warga negara maupun penduduk sebagai orang perseorangan, kelompok, maupun badan hukum yang berkedudukan sebagai penerima manfaat pelayanan publik, baik secara langsung maupun tidak langsung.

Berikut ini kutipanwawancara dengan Lurah Tobekgodang:

"sebagaimana yang telah saya jelaskan tadi, bahwa kami di Kelurahan masih banyak kekurang pada awal pendirian kelurahan ini. Namun semua itu sangat dibantu oleh masyarakat yang mau membantu. Bantuan yang diberikan dapat beri uang dan selanjutnya kami juga meminta partisipasi amsyarakat yang memiliki usaha di sekitar Keruhan Tobek godang untuk mau membantu" (wawancara dengan lurah Tobekgodang) 


\section{KESIMPULAN}

Berdasarkan hasil dan pembahasan yang telah diuraikan oleh peneliti pada bab sebelumnya, maka peneliti menyimpulkan bahwa kesimpulan dari hasil penelitian ini menunjukkan bahwa partisipasi masyarakat di Kelurahan Tobekgodang Kecamatan Tampan sudah efektif dalam rangka peningkatan pelayan publik di Kelurahan Tobekgodang Kecamatan Tampan. namun masih perlu adanya pembenahan sarana dan prasarana, serta ketersediaan sumber daya manusia.

\section{SARAN}

Setelah peneliti melakukan penelitian, kemudian membahas dan menarik kesimpulan tentang efektivitas partisipasi masyarakat dalam peningkatan pelayanan publik di Kelurahan Tobekgodang Kecamatan Tampan, maka peneliti mengemukakan saran perlu adanya perhatian khusus dari pemerintahan Kota Pekanbaru untuk penambahasn dan pembenahan pembenahan sarana dan prasarana, serta ketersediaan sumber daya manusia yang tersedia

\section{DAFTAR PUSTAKA}

[1]. Arikunto. S. 2006. Prosedur penelitian suatu pendekatan praktek. Jakarta: PT Rhineka Cipta.

[2]. Avolio, B.J., \& Gibbons, T.(1988). Developing transformational leaders: Alifespan approach. In.

[3]. Bass, B.M. (1985). Leadership and performance beyond expectations. New York: Free Press.

[4]. Bass, B.M, \& Avolio B.J. (1989).Potential biases in leadership measures: How prototypes, leniency, and general satisfaction relate to ratings and rankings of transformational and transactional leadership constructs. Educational and Psychological Measurement, 49, 505-527.

[5]. Dwiyanto, agus, dkk. 2012. Reformasi birokrasi publik di Indonesia. Yogyakarta: Gadjah mada university press.

[6]. Dwiyanto, agus. 2012. Manejemen pelayanan publik: peduli, inklusif, dan kalaboratif. Yokyakarata: Gadjah mada university press.

[7]. Dwiyanto, Agus. 2014. Mewujudkan Good Governance Melalui Pelayanan Publik.Yogyakarta : Gadjah Mada University Press.

[8]. Fathoni, abdurrahmat. 2011. Metologi penelitian dan teknik penyusunan skripsi. Jakarta: Rineka cipta.

[9]. Halvorsen, Thomas, et al. 2005. On the Differences between Public and Private Sector Innovations. Publin Report. Oslo. 
[10]. Saputra, T., \& Utami, B. C. (2017). Pelatihan Pelayanan Prima Tentang Perilaku Pemberi Layanan Di Kelurahan Sidomulyo Barat Kecamatan Tampan Kota Pekanbaru. Warta LPM, 20(2), 61-66.

[11]. Pasolong, Harbani. 2005. Metode Penelitian Administrasi : untuk organisasi profit dan non profit. Makassar: Lembaga penerbitan Universitas Hasanuddin (Lephas) Rahayu, ami. 2013. 